\title{
Ownership structures and R\&D in Europe: the good institutional investors, the bad and ugly impatient shareholders
}

\author{
BROSSARD Olivier* \\ LAVIGNE Stéphanie** \\ SAKINC M. Erdem ${ }^{* * *}$
}

This version: December 2012

Final version forthcoming in Industrial and Corporate Change, doi: 10.1093/icc/dtt018. First published online: July 5, 2013

\section{Summary:}

This study examines the relationship between ownership structures in large European companies and their innovative activity in terms of R\&D spending. The analysis is performed on a sample of 324 large innovative companies over 8 years. Contrary to the view that institutional investors can have a negative influence on $R \& D$ spending, we report a positive impact of these investors. Our study also tests the impact of 'impatient' institutional investors and provides evidence of their negative influence on $R \& D$ spending.

Keywords: ownership structures, institutional ownership, innovation, R\&D intensity.

JEL: C33, G20, G32, O32

*BROSSARD, O., IEP Toulouse, LEREPS, Toulouse University, olivier.brossard@ univ-tlse1.fr

** LAVIGNE, S., Toulouse Business School, Toulouse University, s.lavigne@esc-toulouse.fr

**** SAKINC, M.E., GREThA, University Montesquieu Bordeaux IV, mustafa.sakinc@ $\underline{\text { u-bordeaux4.fr }}$ 


\section{Introduction}

This empirical study analyses the relationship between ownership structures in large European companies and their search for innovation in terms of $R \& D$ spending. The ownership structures of European companies have experienced radical changes since the early 1980s with the arrival of institutional investors. Institutional investors today hold on average 50 to 60 percent of the capital of large listed European companies and have increased their presence at the expense of 'strategic' investors such as families, industrial corporations and state or government agencies. Concomitant with the presence of institutional investors, a controversy has arisen as to their influence on the 'financialisation' of company strategies (Froud, Haslam, Johal, Williams, 2000; Williams, 2000; Lazonick \& O' Sullivan, 2000) and on the innovative effort of companies in particular. This issue had already arisen in another context, the American case, a few years earlier. In the early 1990s, many scholars attempted to explain the decline of U.S. competitiveness by focusing on the influence of institutional investors on the innovative effort of companies. As an illustration, the work of Porter (1992) explained the decline of U.S. competitiveness, in the late 1980s, by the presence of institutional investors considered as 'myopic' actors seeking only short-term returns. Today, the decline of European competitiveness has become a key issue for industrial policies and in a context of slower growth many questions arise about the systems of corporate governance that could promote innovation.

Since one major dimension of corporate governance concerns the ownership structures of companies, our study focuses on the relationship between ownership structures and corporate innovation strategies. We ask: Who owns companies? Do all shareholders exercise the same influence on the innovation activity of publicly traded companies regardless of their type, nationality or time horizon? And what is the effect of ownership concentration on R\&D spending?

A number of theoretical and empirical studies have already been carried out on the relationship between ownership structures and R\&D investments but these studies were performed almost exclusively in the U.S. context and have produced conflicting results. The first group of studies considers that institutional investors are only motivated by the quest for short-term returns and do not encourage managers to become involved in long-term strategies of innovation, which are risky and uncertain by nature. According to this 'myopic viewpoint', institutional investors do not encourage innovation (Drucker, 1986; Mitroff, 1987; Graves, 1988; Graves, Waddock, 1990; Jacobs, 1991; Porter 1992). The second group supports the thesis that institutional investors look for long-term gains and invest in firms that are more innovative (Jarrell, Lehn, Marr, 1985; Allen, 1993). Finally, the hypothesis of 'myopia' has been challenged by a group of studies reporting that institutional investors, because they hold large stakes in corporations, monitor managers and pressure them to increase long-term investments such as R\&D (Baysinger, Kosnik, Turk, 1991; Hansen \& Hill, 1991; Useem, 1993; Kochar \& David, 1996; Zahra, 1996; Wahal, Mc Connell, 1997; David, Hitt, Gimeno, 2001; Chen, Harford, Li, 2007; Aghion, Van Reenen, Zingales, 2010).

Other studies have focused on another level of analysis claiming that institutional investors do not constitute a homogeneous group. These studies have stressed differences among investors in terms of their time horizons or activism in corporate governance (Roe, 1991; Black, 1992). Different typologies of investors have been proposed including Brickley, Lease \& Smith 
(1998) and Chen et al. (2007) which we refer to in our study. Chen et al. (2007) compare 'grey' and 'independent' investors to assess the influence of different types of investors in corporate governance. 'Grey' owners such as banks, insurance companies, endowments, foundations or private pension funds have a greater potential of close business relations with companies they have invested in and are less likely to challenge managers' decisions. On the contrary 'independent' owners, like mutual funds or public pension funds, have no business relationship with companies and will be much more active in terms of corporate governance.

Since almost all studies focus on the U.S. market, their central issue deals primarily with the influence of different types of institutional investors on innovation. In the European context however, 'strategic' entities still hold an important share of companies' capital, even in large firms with more dispersed ownership (see tables 2, 2, 2'). Such an institutional context is an opportunity to raise an additional question. While in the U.S. context the main issue is whether one type of institutional investor is more favourable to innovation than others, in the European situation it is important to assess whether institutional owners are better at encouraging innovation than other investors and 'strategic' investors in particular. The data we have gathered allow us to address this issue, along with more classical ones such as the influence of ownership concentration, time horizons or the nationality of investors.

To build our European sample, we have focused our attention on the most highly innovative European companies. They can be easily identified thanks to the EU Industrial $R \& D$ Investment Scoreboard of the European Commission. This annual ranking of the top 1000 European companies investing in R\&D accounts for a very large part of European R\&D. Our sample is made up of 324 companies that are present in every Scoreboard's ranking from 2002 to 2009, providing 2525 firm-year observations. We merge these R\&D figures with financial and ownership data provided by Thomson Financial databases.

Our study extends prior research by making empirical and methodological contributions and is original in several respects. The study does not focus on the sole influence of institutional investors on R\&D but incorporates the role of 'strategic' investors that characterize the European institutional context. It tests different dimensions of ownership on R\&D: the type of investor (institutional investors versus 'strategic' entities, 'grey' versus 'independent' investors), their past portfolio turnover ('patient' versus 'impatient' investors), their nationalities and ownership concentration. To the best of our knowledge, it is the first study to test the influence of so many variables of ownership on R\&D with a transnational perspective, on a large sample of companies for an 8-year period. To explain the R\&D effort of companies, we use a standard dynamic investment equation augmented with variables designed to control for the specific determinants of $R \& D$ investment. We use a method to control for endogeneity that is known to be robust for dynamic models: the Blundell-Bond difference Generalized Method of Moments (GMM). It correctly addresses the bias that could come from the inverted direction of causality between institutional stock ownership and R\&D spending.

We report that firms have higher $R \& D$ ratios when their ownership is dominated by institutional investors but lower R\&D ratios when 'impatient' institutional investors (i.e. investors seeking short-term profits) dominate ownership. More precisely, we show that institutional investors' domination has a positive impact on R\&D provided that the blocks of shares held by 'impatient' investors are not too large.

Our paper is organized as follows. Section 2 briefly reviews prior studies on the relationship between corporate ownership and R\&D. Section 3 describes our data, variable definitions and our methodology. Section 4 presents our econometric results. Section 5 concludes our study. 


\section{Corporate ownership and R\&D}

Our study refers to two types of work: 1) works focusing on the relationship between innovation and corporate ownership as a potential influential form of corporate governance; and 2) works based on typologies of investors to provide a better understanding of the relationship between ownership structures and R\&D.

\subsection{R\&D, an investment that generates divergences between stakeholders}

Since the seminal work of Schumpeter (1942), it is recognized that investments in innovation are crucial to economic development and companies' growth. At the discretion of the entrepreneur or management, $\mathrm{R} \& \mathrm{D}$ investments involve risks and temporal trade-offs: investments are carried out in the short term whereas outcomes and payoffs are uncertain and generated over the long term (David et al., 2001). In line with the Schumpeterian theory of innovation, economists have argued that the large size of a company and internal finance were important determinants of the success of $R \& D$ projects ${ }^{i}$. Although many empirical studies have been conducted on the effects of financial constraints on innovation (e.g. Hall, 2002; Bond \& Van Reenen, 2007), there are fewer studies on the relationship between ownership structures and R\&D.

Ownership structures and R\&D investments are two issues often analysed in the agency theory framework. R\&D investments are uncertain and subject to both asymmetric information and moral hazard (Hall, 2002; Aghion et al., 2010). On the one hand, it may be difficult for managers to propose a total disclosure of $R \& D$ projects to outside investors. Indeed, conveying too many details of $R \& D$ investments may affect the firm's competitive advantage (Lee \& O'Neill, 2001). On the other hand, it may be difficult for external investors to supply finance if $\mathrm{R} \& \mathrm{D}$ projects are misunderstood because too opaque. Moreover, the evaluation of an R\&D project generally involves technical or scientific skills and it can be all the more difficult for investors to evaluate projects when companies decline to fully reveal the information necessary to assess the real value of innovation (Mina, Lahr, Hugues, 2012).

From an agency theory perspective, a company's investment in R\&D is a decision that may induce either manager-shareholders conflicts or conflicts between shareholders (through an expropriation of minority shareholders by the controlling shareholders ${ }^{\mathrm{ii}}$ ). The seminal works of Berle \& Means (1932) and Jensen \& Meckling (1976) have underlined the separation of ownership and control that induces potential conflicts of interests between managers and shareholders. Shareholders are supposed to be interested in maximizing the long-term value of their investments (Useem, 1993). R\&D strategies are by nature uncertain and risky, but shareholders whose portfolios are efficiently diversified will be able to spread this risk (Markowitz, 1952). Shareholders may thus be less risk-averse regarding innovation because a decline in one of their investments will not greatly affect the overall value of their portfolios: investment in $\mathrm{R} \& \mathrm{D}$ is a high risk/return strategy attractive to investors able to reduce risk by keeping diversified portfolios (Franko, 1989; Baysinger et al., 1991; David et al., 1996). Managers, on their part, may pursue different objectives including the running of the company, job security, compensation, personal wealth, desire for prestige, etc. Because managers work for a single company, they have undiversified portfolios which may lead them to favour less risky strategies. They may have a general aversion to innovation because of the 
risk of managerial turnover: if $\mathrm{R} \& \mathrm{D}$ projects conclude with failure the board of directors can dismiss managers (David el al., 1996; Kaplan \& Minton, 2012; Aghion et al., 2010). Managers may thus prefer lower-risk strategies with low-variance returns and favour projects with short-term rather than long-term payoffs (Hill \& Snell, 1988; Baysinger et al., 1991; David et al., 1996).

However, the argument according to which the main purpose of companies should be to maximize shareholder value has been questioned by studies trying to propose a theory of innovative enterprise (Lazonik \& Sullivan, 2000; O'Sullivan, 2000; Carpenter, Lazonick, O'Sullivan, 2003; Lazonick, 2009). According to these authors, the agency theory framework is not relevant to explain the process of innovation because it fails to understand under what conditions the allocation of resources really supports investments in R\&D. Yet, this ideology of shareholder value has developed worldwide, since the 1980s, leading large companies to massively distribute corporate revenues to shareholders in the forms of dividends or buybacks instead of fully reinvesting their profits. In their analysis of the innovation process defined as inherently uncertain, Lazonik \& O'Sullivan (2000), O'Sullivan (2000) and Lazonik (2009) have emphasized the role of what they call 'financial commitment'. Companies need a 'financial commitment' or 'patient capital' to sustain investment in R\&D that will generate financial returns in the future through the sales of new products. The role of finance is clearly to provide 'patient' funds able to support the duration and risks of investments in innovation.

According to agency theory, managers should only invest in projects with ' $a$ positive net present value when discounted at the cost of capital' (Jensen, 1986). O'Sullivan (2000) and Lazonick (2007) show that it may be difficult for managers to allocate resources efficiently because investments in innovation only generate returns in the long term. Indeed, one cannot guarantee financial returns to innovative investments because of their inherent risk and uncertainty. If managers were fully dedicated to the maximization of shareholder value, they would probably never invest in innovation. On their part, shareholders and institutional investors in particular, diversify their portfolios to minimize their risk and require financial liquidity whereas investment in innovation requires financial commitment. In practice, O'Sullivan (2000) and Lazonick (2007) show that the ideology of shareholder value has lead companies to use their free cash-flow to repurchase stocks or distribute dividends whereas they could have used profits for innovative investments. The rejection of the agency theory framework is thus sought to be the prerequisite for analyzing and encouraging investments in innovation (Lazonick, 2009).

\subsection{An empirical controversy: do shareholders encourage R\&D?}

Empirical studies have been carried out on the relationship between ownership structures and R\&D and have led to somewhat controversial results (see Kochar \& David, 1996 for a survey). As the majority of studies have focused on the U.S. market, they have analysed the relationship between institutional investors and investment in $R \& D^{i i i}$.

Some studies consider that institutional investors, because they are assessed on a short-time basis only look for short-term gains from their investments (Drucker, 1986; Mitroff, 1987, Graves, 1988; Franko, 1989; Jacobs, 1991; Porter, 1992). These 'myopic' investors lead managers to underinvest in innovation that requires a long-term focus. This 'managerial myopia' has been highlighted in a number of studies to explain the declining position of some countries in international competitiveness (see Porter, 1992, and his analysis of the U.S. market). A number of empirical studies have commented on this negative relationship between institutional ownership and innovation (Graves, 1988; Graves \& Waddock, 1990; 
Majamda \& Nagarajan, 1997; Dixon \& Seddighi, 1996). Graves \& Waddock (1990) have in particular stressed the pressure of quarterly earnings release that negatively influences the propensity of firms to innovate and have commented on this preference of managers for shortterm investments. The study by Lazonick (2007), even if it does not address the relationship between ownership structures and $R \& D$ has focused on the question: do company have invested enough in innovation on the U.S. market in the late 1990s? The study showed that large companies, under the pressure of professional investors, have committed their free cashflow to create shareholder value and have neglected innovation: indeed repurchases programs have exceeded expenditure on R\&D from 1996 to 2000.

Other studies, on the contrary, have concluded that institutional investors only look for longterm returns and invest in companies that are more innovative (Jarrell et al., 1985; Allen, 1993). The study by Jarrell et al. (1985) found that changes in institutional ownership were not associated with change in $\mathrm{R} \& \mathrm{D}$ spending, suggesting that institutional investors have no influence on corporate innovation strategies.

Nevertheless, a large majority of studies support the view that institutional investors take a long-term perspective and are better at monitoring and influencing firms to be more innovative (Baysinger et al., 1991; Hansen \& Hill, 1991; Francis \& Smith, 1995; Kochhar \& David, 1996; Zahra, 1996; Eng \& Shackell, 2001; Aghion et al., 2010). This group of studies underlines the monitoring role of institutional investors by focusing on the relationship between ownership concentration and R\&D investments: a higher institutional ownership is associated with greater innovation. According to this thesis, institutional investors do not select corporations with a higher degree of innovation but rather pressure managers to become involved in strategies for innovation. Institutional investors have incentives to monitor managers and favour R\&D projects: they can pressure boards of directors, exercise their exit options, make public announcements, and so on. The recent study by Aghion et al. (2010) reported a positive impact of institutional investors on $R \& D$ and on the productivity of $R \& D$ (measured by cited-weighted patents per R\&D dollars). Aghion et al. (2010) demonstrated that this correlation between institutional investors and innovation is not due to a selection mechanism whereby investors are better at selecting companies who will innovate more in the future: institutional investors are active shareholders and monitor managers with a view to encouraging innovation. However, all these studies demonstrating a positive relationship between institutional ownership and R\&D have been realized on the US market in the late 1980s and 1990s. One has to underline that this period was characterized by large corporate takeovers, and by a stock market and R\&D boom that may explain part of the correlation found between institutional ownership and R\&D (see O'Sullivan (2004), Lazonick (2007) and Brown et al. (2009) for empirical works on the R\&D boom that has characterized the U.S. market during the 1990s).

\subsection{Typologies of investors and $R \& D$}

Agency theory should be partially amended to acknowledge that shareholders do not all have the same attitude to corporate innovation strategies (Hoskisson et al., 2002). It may be relevant to consider investors as a heterogeneous group: because of the different legal constraints they face, investors have different behaviours in terms of diversification of their portfolios, activism in corporations or portfolio turnover (Roe, 1991; Monks \& Minow, 1995). We believe that integrating typologies of investors should enable us to better understand the relationship between ownership and corporate innovation strategies. 


\section{Type of investors, monitoring and influencing}

Many authors have recognized that the involvement of large shareholders in monitoring and influencing managers has the potential to reduce agency problems (Demsetz \& Lehn, 1985; Shleifer \& Vischny, 1986; Holmström \& Tirole, 1993; Hart, 1995; Maug, 1998, Auvray and Brossard, 2012). In fact, too dispersed shareholders will have no incentives to engage in monitoring because monitoring is costly and small shareholders may hope that others will engage in this activity. Only large shareholders have a real incentive to exercise control over management because unlike small shareholders, they may get a high fraction of the return (Holmström, Tirole, 1993; Hart, 1995). One mechanism that has really affected the monitoring of companies is the emergence of institutional investors (Gillan, Starks, 2000): institutional investors, as large blockholders, can influence managers either through internal mechanism of governance (board of directors or manager compensation policies) or external mechanisms (market for corporate control or trade of shares).

Some studies have proposed typologies of institutional investors based on shareholders' activism, activism being defined as an indicator of shareholder dissatisfaction and designed to bring public pressure on managers (David el al., 1996). Activism of institutional investors includes monitoring and attempting to bring about changes in companies that would not otherwise pursue the goal of maximising shareholder-value. Investors have the potential to influence managers by trading their shares ('exit' strategy or 'voting with their feet') or through their ownership ('voicing' their dissatisfaction). Active investors can vote against management at annual meetings or engage management in discussions (while making shareholder proposals, Gillan \& Starks, 2000). Two studies have integrated this issue of monitoring.

The study of Brickley et al. (1988) opposes three types of investors: i) 'Pressure sensitive' investors include banks, insurance companies and nonbank trusts. These investors have business relations with the firms in which they hold equities and can be reluctant to influence managerial decisions because they could be penalized by the firm via the withdrawal of business; ii) 'Pressure resistant' institutions are public pension funds, mutual funds, endowments and foundations. They have no business relationship with companies but only an investment relationship and can express their opinions of company actions; iii) 'Pressure indeterminate' institutions include corporate pension funds, brokerage houses or institutions with small holdings in the firm and their goals are not clearly defined. Brickley et al. (1998) conclude that 'pressure resistant' investors have the strongest influence on innovation and are in particular more positively associated with the rate of new product development. Following Brickley et al. (1998), Chen et al. (2007) make a clear distinction between 'grey' and 'independent' investors. 'Grey' investors include actors such as banks, insurance companies, endowments, foundations or private pension funds. This category includes long-term investors who have business relationships with companies that may compromise their monitoring activity. 'Independent' investors include public pension funds and investment advisors who do not seek business relationships with companies and who incur the high cost of monitoring. In our study we will test the influence of 'grey' versus 'independent' investors on R\&D policy to integrate this issue of activism.

Empirical studies that have specifically tested this relationship between corporate governance mechanisms and investment in R\&D have concluded that activism has significant but contradictory influence (Baysinger \& Hoskisson, 1990; David et al., 1996, 2001; OrtegaArgilès, Moreno, Caralt, 2005). They have obtained that i) the presence of outside directors on boards leads companies to reduce investment in internal innovation (Baysinger \& Hoskisson, 1990); ii) the activism of institutional investors ${ }^{\text {iv }}$ is positively associated with 
R\&D inputs (David et al., 1996, 2001); or iii) the inclusion of owners in the management of corporations lowers the probability of adopting R\&D projects (Ortega-Argilès et al., 2005).

\section{Strategic versus institutional investors}

'Strategic' investors include families, industrial corporations and state or government agencies. As individual investors, much of their wealth may be invested in a single company. They are not engaged in a strategy of diversification of their portfolios as professional fund managers might be and may thus be more risk-averse to certain decisions such as investments in R\&D. Institutional investors, on the other hand include mutual funds, public and private pension funds, trust funds, private equities, foundations, etc. Because they manage investment for the benefit of others, institutional investors are required by law to hold diversified portfolios (Roe, 1991) and have a fiduciary obligation to maximize long-term value (Davis \& Thompson, 1994; David et al., 2001). Institutional investors are not sensitive to the decision of investment of a single company that would only slightly affect the performance of their overall portfolio and may not be reluctant to invest in companies engaged in innovation.

'Strategic' investors are historical reference shareholders in many European countries such as France where, as majority shareholders, they may hold a large fraction of shares ${ }^{\mathrm{v}}$. Institutional investors, meanwhile, are the reference shareholders of Anglo-Saxon countries, with U.S. institutional investors holding $60 \%$ of the capital of large U.S. companies (Hawley \& Williams, 2000; Aghion et al., 2010). To the best of our knowledge, no study has investigated the relationship between 'strategic' versus institutional investors and R\&D. Our study is original because it tests the influence of these two kinds of investors on R\&D investments while postulating i) a negative relationship between 'strategic' investors and R\&D; ii) a positive influence of institutional investors on $R \& D$.

\section{Type of investors and time horizons}

The question of time horizon is a crucial issue for an understanding of the relationship between investors and R\&D policy. Lazonick \& 0'Sullivan (2000) and Lazonick (2007) have emphasised the importance of 'financial commitment' or 'patient capital' to sustain investments in R\&D. As not all investors have a long-term orientation, it is necessary to determine who the 'patient' versus 'impatient' investors are, in order to assess what kind of investor really encourages innovation. Two empirical studies that particularly focus on this issue of time horizon have largely inspired our study.

The study by Bushee (1998) classifies institutional investors according to their past trading behaviour while drawing on the typology of Porter (1992). His classification is based on three variables: portfolio turnover (a measure of how frequently an investor trades shares of the firms in its portfolio), diversification of the portfolio (a measure of whether an investor tends to take small ownership positions in a large number of corporations or large ownership positions in a small number of firms) and momentum trading (a measure of whether an investor increases its holding in corporations that have just announced surprise positive earnings and decreases its holdings in corporations with bad earnings news). Bushee (1998) distinguishes i) 'transient' investors (high portfolio turnover, high diversification and high degree of momentum trading) characterized by short-term horizons; ii) 'dedicated' investors (low portfolio turnover, low diversification and no trading activity for short-term earnings) that hold their stakes for long periods of time; iii) 'quasi-indexer' investors (low portfolio turnover, high diversification and passive buy-and-hold investing strategies). Bushee (1998) 
demonstrates that, as a whole, institutional investors reduce incentives for managers to act myopically. Cuts in R\&D following poor earnings performance are less likely, the greater the degree of institutional ownership. In particular, managers of companies with high levels of 'transient ownership' face the strongest incentives to make myopic decisions: a large proportion of ownership by institutions that have high portfolio turnover increases the probability that managers reduce $\mathrm{R} \& \mathrm{D}$ to reverse an earnings decline.

The study of Dupuy, Lavigne and Nicet-Chenaf (2010) provides a comparative study of portfolio turnover among worldwide investors. It questions the thesis that institutional investors require high returns on invested capital in a short time period, contributing to the 'financialisation' of corporate strategies. Their study opposes 'strategic' investors (the state, families, corporations, banks and insurance companies) and institutional holders (pension funds, mutual funds, private equities, hedge funds, etc.). The most volatile actors are, in descending order: hedge funds, mutual funds, endowment funds and brokers/dealers, the least volatile actors being the state, individuals and corporations, whereas banks, insurance companies and pension funds occupy a middle position in terms of portfolio turnover. Their study emphasizes that American investors trade securities most frequently relative to other international equity investors, confirming that the United States is the archetype of 'financedriven' capitalism. The study of Dupuy et al. (2010) highlights two factors that can be central for understanding time horizons of investors and by extension their influence on innovation: the type of investor (mutual fund, pension fund, hedge funds, etc.) and its nationality. We believe that these two variables deserve to be included in any study seeking to analyse the relationship between institutional ownership and investments in R \&D.

\section{Pension funds versus mutual funds}

Institutional investors differ in respect to their legal environment, modes of collecting funds and issuing payments, time horizons and liquidity constraints (Roe, 1990; Black, 1992; Goyer, 2006). In particular, pension fund and mutual fund managers have different behaviour detailed in the study by Hoskisson et al. (2002) who test the relationship between institutional holdings and investment in $\mathrm{R} \& \mathrm{D}$ while comparing pension funds to mutual funds. Because pension fund managers have to pay a retirement pension to their pensioners, they are under no pressure to achieve short-term returns. They operate within a regulatory framework that limits their holdings in companies and their compensation is not market-based (Scharfstein \& Stein, 1990; Bethel \& Liebeskind, 1993). Pension funds, and particularly public pension funds, are active in the governance of companies principally through the submission of shareholder proposals $^{\mathrm{vi}}$. For these reasons, pension fund managers may focus on companies with longterm strategies and may prefer internal innovation to external innovation through acquisition (Hoskisson et al., 2002). On the contrary, professional fund managers, because they are likely to be replaced if their performance is not sufficient in the short-term (Khorana, 1996) will pursue short-run horizons. Managers of mutual funds are compensated according to the size or net asset value of the fund. Hoskisson et al. (2002) demonstrate that mutual funds consider $\mathrm{R} \& \mathrm{D}$ investments as an expense that reduces short-term performance and will prefer external innovation that generates more immediate returns.

In summary, the literature has shown that several variables can influence R\&D policy, namely the type of investor, its degree of activism in corporations, its time horizon or its nationality. Rather than testing the influence of one or two variables, as it is usually the case in many studies, the Thomson Financial database allows us to test these four variables of ownership in a single study. In particular, we will assess whether $i$ ) long-term institutional investors favour 
R\&D investments; ii) 'strategic' investors and 'impatient' institutional investors negatively affect R\&D expenditure ${ }^{\text {vii }}$.

\section{Data, variables and methodology}

\subsection{The sample}

To study a transnational sample of European companies, no representative firm-level data is available. However, it is possible to identify a large sample of the most innovative European firms thanks to the annual EU Industrial R\&D Investment Scoreboards prepared by the Joint Research Centre and the European Commission's Directorate-General for Research and Innovation $^{\text {viii }}$. Every year since 2004, the EU R\&D Scoreboard provides R\&D expenditure for the top 1000 EU companies and top 1000 non-EU companies investing in R\&D. The ranking is based on the previous year's R\&D figures, but the first ranking issued in 2004 provides R\&D data for 2000, 2001, 2002 and 2003. Despite its limitations due to slightly different national accounting standards and disclosure practices, the EU Scoreboard is probably the best tool for companies, investors, financial analysts, policy makers and governments to study R\&D expenditures at a company level. The data are taken from companies' publicly available audited accounts and do not include information on where R\&D was performed ${ }^{\mathrm{ix}}$. Among the firms in the top 1000 ranking of the EU R\&D Scoreboards, many are listed for only a few years because they do not constantly maintain a top level $R \& D$ expenditure, or because they disappear for other reasons (failure, mergers \& acquisitions, etc.). The system-GMM procedure we implement to deal with endogeneity in the econometrics requires at least 4 years of continuous data because it uses the second lags of the variables differences as instruments. In order to maintain time variability in the data once these lags and differences are introduced, it is necessary to use as many years as possible of continuous data. Otherwise, the dataset would become a pseudo-panel where most of the variance would come from between-firm variability, whereas within- firm variability would be nearly absent. We therefore identify a sub-sample of 331 companies that 1) are present in every Scoreboard ranking between 2004 and $2010^{\mathrm{x}}$ and 2) have no missing R\&D expenditure figures from 2002 to $2009^{\mathrm{xi}}$. These 331 firms are substantial innovators since they have ranked among the top $1000 \mathrm{R} \& \mathrm{D}$ firms for seven years (2004-2010). We merge these R\&D figures with financial and ownership data provided by two Thomson Financial databases: Worldscope Fundamentals and Thomson One Banker Ownership (TOBO) ${ }^{\mathrm{xii}}$. Ownership data are available from 2002 onwards. After removing seven firms for which ownership data were not available, we end up with a slightly unbalanced panel of 324 firms over the period (2002-2009).

Table A1 (Appendix) shows that, according to the SIC 2-digits classification, the six most frequent industrial sectors in the sample are, respectively, Electronic and electric equipment, Chemicals and allied products, Industrial machinery and equipment, Business services, Transportation equipment and Instruments and related products. Considering the 4-digits level, the three most frequent sectors are, respectively, Prepackaged software, Pharmaceutical preparations and Semiconductors. Not surprisingly, firms in the ICT, Pharma-medical, Electronic or Automotive sectors are more frequently classified in the top $1000 \mathrm{R} \& \mathrm{D}$ ranking and are consequently over-represented in the sample. As regards firms' size, Table A2 (Appendix) shows that a large proportion of the sample is made up of large-scale businesses: between 2002 and 2009, the smallest company of the sample never falls below 56 employees; only $5 \%$ of the sample have fewer than 290 employees; only $50 \%$ have fewer than 6130 employees, $25 \%$ exceed 26,797 employees and 1\% exceed 321,090 employees. This over- 
representation of large and very large businesses is not surprising in a sample of highly innovative firms where large automotive and pharmaceutical firms are pooled with smaller software and electronics companies. The distribution of firms between countries is also characterized by over-representation of some countries (Table A3, Appendix). Indeed, our data confirm that some countries lag behind in terms of their R\&D effort (Spain, Greece, Italy, Poland) while others have a larger proportion of firms in the top 1000 R\&D Scoreboard than might be expected regarding their size (Denmark, Finland, Sweden, Netherlands, U.K.).

Even if this sample of the most innovative European firms is not representative of the whole European population of companies, understanding the behaviour of this particular group of companies is a relevant issue. According to the Joint Research Centre of the European Commission, the top 1000 companies account for a very large part of world total R\&D, around $85 \%$ in 2009. This is an appropriate sample to analyse the behaviour of the most innovative European firms.

\subsection{Variables and descriptive statistics}

There are several important papers in the literature showing that $\mathrm{R} \& \mathrm{D}$ can be interpreted as a kind of investment and that the financing constraint is particular in the case of $R \& D$ investments (Mulkay et al., 2001; Bond et al., 2005, Brown et al., 2009) ${ }^{\text {xiii }}$. As a consequence, to explain the R\&D effort for large European companies, we use a standard dynamic investment equation inspired by these studies and augmented with variables designed to control for the specific determinants of $R \& D$ investment. We then introduce various ownership variables to assess the potential impact of firms' shareholder characteristics. Dependent and independent variables are presented in Table 1.

To measure the $R \& D$ effort, the natural dependent variable is a ratio of $R \& D$ expenditure over a scaling variable accounting for firms' size. Although some studies use sales or the number of employees as scaling variables, theoretical models of investment applied to R\&D suggest using assets as the scale variable in R\&D investment regressions (Brown et al., 2009). We will therefore present our results with the dependent variable (R\&D expenditure / total assets $)^{\text {xiv }}$.

We explain this R\&D effort measurement by independent variables suggested by investment theories. The first is lagged $R \& D$ because investment is subject to adjustment costs that create persistence in this variable. Moreover, innovative projects often take a substantial amount of time to come to fruition. Therefore, the adjustment costs of R\&D may be particularly high (Himmelberg \& Petersen, 1994; Hall, 2002). We employ a dynamic specification of our R\&D investment equation requiring a specific GMM estimator. A usual explanatory variable for investment is Tobin's Q. In line with many other studies, we approximate Tobin's Q with the ratio (market capitalization + total debt) / (total assets). Another potentially important determinant of $R \& D$ investment is profitability, either because it is a measure of demandinduced R\&D investment (accelerator mechanism) or because it captures the importance of the financing constraint (Fazzari et al., 1988; Hubbard, 1998) or the cost of other production factors (Brown et al., 2009). We measure profitability with a ratio derived from firms' income statement: return on sales (ros) which is the ratio (net income / sales). More precisely, we use one-year lagged values of this ratio in order to limit its colinearity with Tobin's Q. Since expected demand may not be perfectly captured by the proxy we use for Tobin's Q, we use a sales-to-assets ratio to control for demand effects on R\&D and assess whether our results are robust to this inclusion. 
We then introduce control variables accounting for the specificity of $R \& D$ as an investment. First, R\&D investment is influenced by the intensity of the technological competition that characterizes the industry in which a company operates. To capture this effect, we use the standard OECD classification of industrial sectors into four technological levels (low tech, mid-low tech, mid-high tech and high tech). Not surprisingly, $44 \%$ of the firms in this sample belong to high-tech industries while only $10 \%$ belong to low-tech sectors (Table 1). Of course, the technological level is highly correlated to the industry classification and it is therefore useless to control for industry affiliation on top of that. Another important control variable is the size of the firm because it influences its market power, financial constraint and technological opportunities. Since assets and sales already serve as scaling variables, one cannot use them as size controls. We therefore introduce firms' total number of employees in all estimated equations. We also create dummies to control for firms' nationality (variables UK, German, Nordic and Latin in Table 1), and introduce year-dummies in all regressions. As a supplementary robustness test, we introduce control variables accounting for firms' financial strategies and financial constraints: a total debt to income ratio, a balance sheet cash ratio, a share buyback ratio and a dividend ratio.

\section{PLEASE INSERT TABLE 1 ABOUT HERE}

Most importantly, the core innovation of this study is that we construct various measures of firms' ownership characteristics and assess their influence on R\&D investment. The data extracted from the TOBO database provide detailed information about the geographical origin of shareholders, their type (pension fund, hedge fund, bank, corporation, holding, etc.), their investment horizon (portfolio turnover) and the percentage of the firm's shares they hold. This information is updated quarterly and detailed not only for the most important shareholders, but also for a large part of total ownership. In our sample, more than $75 \%$ of firm-year observations have more than $40 \%$ of their total share ownership described in the TOBO database. This is quite enough, as the literature on ownership structures, monitoring and corporate control generally considers that focusing on the five or ten most important shareholders is sufficient to understand the influence of significant blockholders. We build ownership variables considering the ten largest shareholders. Firstly, the influence of shareholders may be related to ownership concentration because it encourages monitoring and activism aiming at influencing managers' decisions. That is why we test the two classical ownership concentration indices: $c 1$ (\% of shares held by the main shareholder) and $c 5$ (\% of shares held by the top five shareholders). Table 1 shows that, on average, ownership is fairly concentrated in our sample of highly innovative European firms. However, $c 1$ and $c 5$ have important standard errors. Secondly, we wanted to find out whether the national origin of shareholders could have an influence on companies' R\&D. We construct a measure of investors' dominant origin by bringing together countries that are close in the geographical, linguistic or institutional dimension. The dummy duanglo has a value of one if the percentage of shares held by Anglo-Saxon investors among the ten most important shareholders is higher than the share held by European or other investors. Table 1 shows that $35 \%$ of the firms in this sample have ownership structures dominated by Anglo-Saxon investors while $64 \%$ have ownership dominated by European investors. Similarly, we create a dummy duii equal to one if, among the ten most important shareholders, the percentage of shares held by institutional investors is higher than the percentage held by strategic entities. In the TOBO database, the type 'strategic' entities refers to holding companies, individual investors, corporations or government agencies. Other investors are called 'investment managers' and are actually 
institutional investors with a subtype label 'investment advisors', 'hedge funds', 'banks \& trusts', 'sovereign wealth funds', 'pension funds', 'venture capital funds' 'research firms' or 'private equity funds'. On average, institutional investors belonging to the ten most important shareowners hold $23.7 \%$ of the total outstanding shares while strategic entities hold $20.8 \%$ (variables iistake and stratstake in Table 1). Ownership is consequently 'dominated' by institutional investors (duii=1) in $60 \%$ of cases, which means that there are $40 \%$ of companies in the sample where, among the ten largest shareholders, the percentage of shares held by institutional investors is lower than the percentage held by 'strategic' entities. In this regard, Europe is very different from the US where institutional investors dominate ownership in a large majority of companies. However, Table 2 shows that whereas the first shareowner is frequently a strategic investor in our sample, the fifth or tenth investor is most often an institutional one. We also construct a variable designed to assess the influence of 'impatient' investors, impatientstake, which is the share of total outstanding stocks held by 'impatient' investors that belong to the ten most important shareholders. We consider an 'impatient' investor to be any shareholder whose portfolio turnover is qualified as 'moderate' or 'high' in the TOBO database. High portfolio turnover refers to a holding period of portfolios of less than 18 months. Moderate portfolio turnover refers to a holding period between 18 months and 24 months. Low portfolio turnover refers to a holding period of more than 24 months. On average, the share of 'impatient' investors is 5.2\% (Table 1). Table 2 shows that 'impatient' investors represent only $11 \%$ of the first shareholders but are found more frequently among the fifth or tenth shareholders (respectively $23.7 \%$ and $25.5 \%$ ).

We have also attempted to introduce a variable accounting for the distinction between 'independent' and 'grey" investors. This was inspired by the studies by Brickley et al. (1988) and Chen et al. (2007). We therefore created a dummy variable, duindep, which is equal to one if ownership is dominated by 'independent' investors, that is to say institutional investors that are neither banks nor insurance companies. We see in Table 1 that the figures concerning the distribution of shareholdings between institutional investors and 'strategic' entities (duii=1 in $60 \%$ of cases) do not differ much from the ones regarding the distribution between 'independent' and 'grey' investors (duindep $=1$ in 58\% of cases). Indeed, the only difference between these two typologies is that banks and insurance companies are always classified as institutional investors in the former while they are classified as 'grey' investors in the latter, if they do not hold the shares through one of their asset management branches. This case is extremely rare in the TOBO database where banks and insurance companies appear very rarely under the type code 'Banks \& Trusts' because they are almost always asset management branches and hence categorized as 'investment managers'. Using the TOBO database and its investor type codes therefore results in many banks being coded 'independent' whereas a number of them would certainly be considered as 'grey' investors by Brickley et al. (1988) and Chen et al. (2007), even if they hold the shares through their asset management branches. However, we think that it is somewhat arbitrary to decide whether the asset management branch of a particular bank behaves like an 'independent' investment manager or rather like a 'grey' investor. Furthermore, this behaviour may vary with the size of the shareholding: a bank may act like a 'grey' investor when it is the first blockholder of the company, and like a portfolio manager when it is the fifth or tenth shareholder of the company. These difficulties lead us to focus on the distinction between 'strategic' investors and institutional investors rather than on the difference between 'independent' and 'grey' investors. As underlined in Section 2, the European case is specific and interesting because of the large share of stocks held by strategic entities that probably do not behave like institutional investors: these are holding companies, corporations, and individual investors whose portfolios are much less diversified than those of institutional investors. Therefore, there are good reasons to expect that they are more reluctant to bear the risks of long-term 
R\&D investment even if their investment horizon is always above 24 months, whereas more than $20 \%$ of institutional investors can be characterized as 'impatient' (Table 2). Tables 2' and 2" show the nature and behaviour of the main institutional investors in our sample. Investment advisors (i.e. mutual funds) and hedge funds are the most frequent investors and represent the great majority of institutional investors (Table 2'). Whereas $20.82 \%$ of institutional investors registered as first shareholder are 'impatient' (Table 2), only $13.51 \%$ of private equity funds, $0 \%$ of pension funds and $3.57 \%$ of Banks \& Trusts are 'impatient' investors (Table 2'). These latter types of funds are more patient than the others. On the contrary, investment advisors, hedge funds and research firms tend to be more 'impatient' investors. It should also be underlined that some investors do not behave the same way when they are the first or only the tenth shareholder: investment advisors, private equity funds and banks \& trusts are more 'impatient' when they are only the fifth or tenth shareowner and they are more 'patient' when they are the first (Table 2', ).

\section{PLEASE INSERT TABLES 2, 2' and 2"' about here}

\subsection{Econometric methodology}

In our R\&D investment equations we test all the ownership variables described above (Table 1) in order to systematically assess these various dimensions of the ownership effect. On this sample of firms, two ownership variables prove to have significant and robust effects on the R\&D effort: duii, which describes whether or not the ownership is dominated by institutional investors, and impatientstake, which captures the influence of 'impatient' blockholders.

We therefore focus on the following dynamic equation (Equation (1)):

$$
\begin{aligned}
& \text { rdtoasset }_{i t}=\alpha+\beta_{1} \text { rdtoasset }_{i t-1}+\beta_{2} \text { Tobinq }_{i t}+\beta_{3} \text { ros }_{i t-1}+\sum_{j} \gamma_{j} \text { TIcontrol }_{i j}+\sum_{j} \delta_{j} \text { TV } \text { control }_{i j t} \\
& +\lambda \text { duii }_{i t}+\text { uimpatientstake }_{i t}+\sum_{t=2002}^{t=2009} \pi_{t} \text { year }_{t}+u_{i}+\varepsilon_{i t}
\end{aligned}
$$

whose variables have already been described above (Table 1):

- rdtoasset ${ }_{i t}$ represents R\&D expenditure over total assets for firm $i$ at time $t$;

- $\operatorname{ros}_{i t-1}$ is the return on sales ratio computed with net income;

- TIcontrol ${ }_{i j}$ represents the set of time-invariant control variables, that is to say hightech, German, Nordic and $\operatorname{Latin}^{x v}$;

- TVcontrol $\mathrm{ijt}_{\mathrm{jt}}$ is a set of time-variant controls: salestoassets, employees ${ }^{x v i}$, debttoinc, cashtoinc, buybacktoinc, divtoincome;

- year $_{t}$ are time period fixed effects for the years 2002-2009;

- duii $_{i t}$ is a dummy equal to 1 if firm $i$ 's ownership is dominated by institutional investors at time $t$

- impatientstake $e_{i}$, is the share of total outstanding stocks held by "impatient" investors that belong to the ten most important shareholders of firm $i$ at time $t$;

- $u_{i}$ is an unobserved individual effect; 
- $\varepsilon_{i t}$ is the usual idiosyncratic error term;

Several econometric problems have to be addressed when estimating such an equation. Firstly, the estimated standard errors have to be corrected for heteroskedasticity because of the structure of the panel data. This is done in all our regressions. Secondly, unobserved heterogeneity, in the time dimension and in the individual dimension, is a serious concern. Consequently, we systematically introduce time-period fixed effects in all estimations. We also introduce two kinds of individual fixed effects: the dummies German, Nordic, Latin accounting for firms' national locations and the dummy hightech indicating whether the firm belongs to a high-tech industry. However, since we want to obtain estimates of these dummies coefficients, we cannot use simple 'within' estimators because they would exclude all timeinvariant dummies. Moreover, a simple 'within' estimator would not be appropriate for this dynamic equation which includes the lagged dependent variable among the explanatory variables. A third important econometric issue is that we suspect that an endogeneity bias could be generated by the fact that institutional investors select the most highly innovative firms to get higher returns from their investments. If such firms do more $R \& D$ than the others because they have high-potential research projects that we do not observe but that institutional or 'impatient' investors may be aware of, the presence of these investors will be correlated with the unobserved individual effect $\mathrm{u}_{\mathrm{i}}$ and possibly also with $\varepsilon_{i t}$, the idiosyncratic error term. To treat this endogeneity problem, we use GMM techniques that rely on lagged values of independent variables to instrument the endogenous variables. We cannot use the ArellanoBond (1991) estimator because we wish to obtain estimates of the hightech and country group dummies, which is impossible with the difference-GMM approach. Blundell \& Bond (1998) suggest a system-GMM approach in which the model parameters result from simultaneously estimating the equation in difference and in level, using lagged differences as instruments for the levels and lagged levels as instruments for the differenced variables. This method will offer consistent estimators of the dynamic Equation (1), provided that the 'moment' conditions are validated and that the estimated models do not exhibit order 2 serial autocorrelation $^{\text {xvii }}$. We validate the former condition using the Sargan test, and the latter using Arellano-Bond tests for order 2 autocorrelation in first-differenced errors. This method has the great advantage of fully addressing endogeneity since it is consistent with the potential correlation between some selected covariates and both the individual error term $u_{i}$ and the idiosyncratic one $\varepsilon_{i t}$. We choose to instrument the variables duii and impatientstake for reasons already explained hereinbefore. In the equation where we introduce supplementary financial controls, we also instrument the variable buybacktoinc because we suspect that it is correlated to the idiosyncratic error term $\varepsilon_{i t}$ since richer firms may implement supplementary $\mathrm{R} \& \mathrm{D}$ while also using their excess cash to repurchase their shares.

\section{Econometric estimates and results}

We first implement the dynamic system-GMM estimation with the main explanatory variables (Table 3, column 1). This specification is validated by two usual tests: the Arellano-Bond test accepts the hypothesis of no second order autocorrelation of the first-differenced errors. The Sargan test validates the over-identifying restrictions. These two tests validate all the specifications presented in Tables 3 and 4, which means that the equations and their internal instruments are correctly specified.

The highest and most significant coefficient is that of lagged R\&D to assets. In this sample of companies, a doubling of the R\&D ratio at time $t$ generates a $50 \%$ increase of the R\&D ratio 
at time $t+1$. It suggests that adjustment costs of $\mathrm{R} \& \mathrm{D}$ investment are rather high and produce a significant persistence of the $R \& D$ effort. The choice of a dynamic equation for the $R \& D$ investment is therefore justified. Tobin's $\mathrm{Q}$ has a positive but non-significant coefficient in this regression and in all the other specifications presented below. However, one can verify that it again becomes significant if one adopts a static rather than dynamic specification of the R\&D effort equation ${ }^{\text {xviii }}$, or if one removes the lagged cash-flow variable (return on sales). Therefore, Tobin's $\mathrm{Q}$ is not significant, because lagged $\mathrm{R} \& \mathrm{D}$ and the other significant explanatory variables capture most of its explanatory power. The value of a one-year lagged cash-flow variable $\left(\operatorname{ros}_{t-1}\right)$ is significant positive but its impact on the $\mathrm{R} \& \mathrm{D}$ effort is small. On the contrary the fixed effect technological level hightech is positive, significant and fairly high in all specifications: belonging to a high-tech sector rather than to a mid or low-tech one leads on average to a $10 \%$ higher $\mathrm{R} \& \mathrm{D}$ ratio. On the contrary, the country type dummies are not significant in this first regression.

Most importantly, the dummy variable duii has a positive and significant coefficient of 0.037 which represents more than $46 \%$ of the R\&D-to-assets standard error (displayed in Table 1). An ownership dominated by institutional rather than 'strategic' investors substantially boosts the $R \& D$ ratio in this sample of highly innovative companies. However, we also obtain a significant and negative coefficient of the variable impatientstake measuring the share of total outstanding stocks held by 'impatient' investors belonging to the ten most important shareholders. The coefficient is -0.003 which implies that a one-standard-deviation increase of the share of 'impatient' investors, that is to say a $6.7 \%$ variation of their shares, generates a drop of $2 \%$ of the R\&D-to-assets ratio, which has an $8 \%$ standard error. The negative impact of 'impatient' investors is not negligible.

\section{PLEASE INSERT TABLE 3 ABOUT HERE}

To test robustness, we first introduce the demand variable salestoassets and the financial controls debttoinc, cashtoinc, divtoincome and buybacktoinc (Table 1, column 2). The former is positive and strongly significant but the latter are not significant. Consequently, we do not use them further in the other specifications. In any case, inclusion of these variables does not change either the signs or significances previously obtained for the main coefficients. In particular, the two ownership measures duii and impatientstake keep their significances and signs. However, two variables now become significant: lemployees, which is the log of the number of employees and Latin, which is the dummy identifying French, Italian, Spanish, Greek or Belgian companies. A natural explanation for the fact that the size variable lemployees is, in some specifications, significant negative, is that smaller companies are constrained to innovate a great deal because they want to conquer markets whilst larger firms may benefit from various monopoly rents - for example those due to increasing returns of technological adoption that render the innovative effort less vital. The positive and sometimes significant effect of the dummy Latin has to be interpreted very cautiously. The reference category is the dummy $U K$ identifying English and Irish firms. This means that, in this sample of companies, the Latin firms have on average higher R\&D-to-asset ratios than the U.K. firms, but this is also the case of German and Austrian firms though the coefficient of the dummy German is only significant in one specification (Table 4, column 2). Moreover, we know from Table A3 (appendix) that Latin countries are under-represented in this sample of very innovative corporations. This might bias upward the coefficient of the dummy Latin. 
A supplementary robustness test is provided in Table 3, column 3: to check that our results are not driven by outliers, we winsorize all the scale variables (assets and sales) used in the ratios. This winsorization at $0.5 \%$ on each tail of the distribution does not cause any significant changes.

The positive effect of duii and the negative effect of impatientstake appear to be robust. This suggests that institutional investors have a positive influence on $R \& D$ when they dominate ownership, i.e. when they have a larger share than strategic investors among the ten first shareholders. Furthermore, 'impatient' investors have a negative influence on R\&D, even if they hardly ever dominate ownership structures of this sample of companies (Table 2). In fact, all 'impatient' investors are institutional investors (Table 2). Therefore, the correct interpretation is that institutional investors' domination has a positive impact on $R \& D$ provided that the blocks of shares held by 'impatient' ones are not too large ${ }^{\text {xix }}$.

\section{Are the results produced by reverse causality?}

One could argue that 'patient' institutional investors intentionally choose to hold more R\&Dintensive stocks, meaning that this econometric result must be interpreted as evidence of the reverse causation going from the nature and level of firms' investments to the nature of the investors they attract. We cannot totally exclude this explanation as there are good reasons to consider that diversified institutional investors with long investment horizons select companies whose investment expenditure is highly lucrative but risky and long to become profitable, which is particularly true in the case of R\&D investments. However, why would such investors change their view and discourage R\&D investment once they have bought the stocks? Furthermore, all the econometric specifications implemented in this study address the potential endogeneity of the two ownership characteristics duii and impatientstake. This means first that the level of their coefficients is not biased by this possible reverse causation. Secondly, since these two variables are instrumented by their lagged and differenced values, one cannot reject the causality going from the nature of investors to the level of R\&D, even if one cannot exclude the reverse causation: if patient institutional investors where selecting $R \& D$ intensive stocks to discourage $R \& D$ once they hold the stocks, the instrumented versions of duii and impatientstake would not have significant positive coefficients because their lagged and differenced values would be correlated negatively with the R\&D ratio. If only the reverse causation was involved, we would not obtain these signs for the variables duii and impatientstake instrumented this way.

\section{Does the influence of institutional investors vary with the size of companies?}

To assess whether the key results for the investor type variables differ with size, we interact the number of employees with the variables duii and impatientstake. For that purpose, we create a dummy dbig equal to 1 whenever the company belongs to the $50 \%$ of firms with the highest number of employees, and we interact this dummy with duii and impatientstake. The results provided in Table 4, column 1 show that the positive influence of institutional investors in comparison to strategic entities is significant whatever the firm size. However, the negative influence of the share of impatient (institutional) investors is significant only for the $50 \%$ of smallest companies. First, one has to underline that in any case these are not very small firms as the median firm size in the sample is 6130 employees (Table A3, Appendix). Secondly, to interpret this latter result, we checked the shares of impatient investors in each size category. The average share of impatient investors is $7.1 \%$ in the smallest firms whereas it is only $3.3 \%$ in the largest ones. Consequently, there may be a minimum threshold of the share of 'impatient' investors to produce a negative influence on $R \& D$. We verify this 
hypothesis in the specification presented in Table 4, column 2. We interact the variable impatientstake with a dummy dhighturnov equal to one whenever the share of 'impatient' investors is above the median share observed across the sample. The negative impact of impatientstake proves to be significant only when dhighturnov is equal to one. In conclusion, 'impatient' investors have a significant negative influence on R\&D in this sample, but only in the firms with fewer than 6130 employees because these are the only companies where these investors manage to reach a stake sufficient to be influential. Smaller corporations may be more influenced by 'impatient' investors because they have smaller capitalisations and, consequently, more open ownership structures. In larger capitalisations, a coalition of 'impatient' investors planning to grab the free cash-flow rather than invest in long-term R\&D projects is much less feasible because ownership is necessarily more dispersed. Another complementary explanation is that smaller companies are probably younger on average, and so they rely more heavily on some external equity financing that they cannot easily replace with debt (Brown et al., 2009).

\section{PLEASE INSERT TABLE 4 about here}

\section{Conclusion}

We estimated R\&D intensity equations on 324 European firms that have been constantly classified between 2004 and 2010 in the top 1000 EU companies ranked by R\&D expenditure according to the annual EU Industrial $R \& D$ Investment Scoreboard. We assembled a panel dataset including $R \& D$ expenditure, accounting information and ownership details for all these 324 firms over the period (2002-2009).

We used this dataset to assess whether ownership characteristics have a significant and robust influence on the R\&D effort of this sample of European companies. A preliminary review of the theoretical and empirical literature shows that the effect of ownership structures on R\&D is still controversial, especially in the European case since it has been somewhat neglected by empirical studies. There are good theoretical reasons to suspect that corporate strategies are influenced by ownership concentration and investor characteristics, particularly in the case of long-term decisions such as R\&D investment. For example, large blockholders have to monitor and influence managerial decisions because they have large stakes in firms' capital (Holmström \& Tirole, 1993, Auvray and Brossard, 2012). Investors' country of origin may produce specific monitoring behaviours because of the different national legal systems governing asset management practices (Dupuy et al., 2010). Moreover, institutional investors that manage portfolios by delegation have different risk/return benchmarks than strategic investors whose asset allocation is necessarily oriented by business goals. One could also suspect that monitoring/influencing practices are different across various groups of institutional investors since this broad category of investors merges, for example, pension funds, venture capital funds, sovereign funds and so on (Roe, 1991; Monks \& Minow, 1995). Finally, there are also some very good reasons to suspect that 'transient' or 'impatient' investors do not stay long enough in firms' capital to correctly reward such long horizon investments as R\&D expenditure (Porter, 1992, Lazonick and O’Sullivan, 2000).

We exploited Thomson One Banker Ownership data to test the influence of these ownership characteristics on $R \& D$ intensity ratios. We found that two ownership variables have a significant impact that proves robust to specification tests and that resists correction of 
endogeneity biases. The first, duii, is a dummy characterizing ownership structures dominated by institutional rather than strategic investors; its coefficient is positive. The second, impatientstake, characterizes the share of total outstanding stocks held by 'impatient' investors that belong to the ten most important shareholders; its coefficient is negative. We can therefore conclude that, in our sample of European firms, institutional investors seem to promote R\&D investment while 'impatient' investors seem to hinder it. A comprehensive examination of the nature of impatient investors in this sample shows that they are not strategic investors, which is not surprising, but particular types of institutional investors: mainly mutual funds and hedge funds. Therefore, institutional investors have a positive impact on R\&D provided that these 'impatient' institutional investors do not hold too large blocks of shares. Of course, this does not provide empirical identification of why and how they do so. Indeed, as argued by David et al. (2001), ownership alone may not be a sufficient explanation and it could be interesting to integrate the actions by which institutional investors exercise their influence. Other empirical studies should try and elucidate these points. One can easily understand that 'impatient' investors exert pressures in favour of strategies that produce immediate profitability, high stock prices and high dividends in the short run, but why would institutional investors support $\mathrm{R} \& \mathrm{D}$ expenditure more than 'strategic' investors? Is it because the former are activist investors while the latter are passive shareholders? Is it because they are independent outsiders while strategic investors have business ties with companies they invest in and therefore tend to favour manager entrenchment (Shleifer \& Vishny, 1989)? Or is it on the contrary because managers have superior ability to understand what kind of R\&D investments are relevant but need the support of long-term institutional investors to implement such policies (Aglietta \& Rigot, 2009; Lazonick \& Prencipe, 2005)? These competing interpretations require further empirical investigations with more precise data on shareholder behaviour, manager compensation and strategic control on company boards. Moreover, since focusing on $R \& D$ alone may be misleading because it supposes that more $\mathrm{R} \& \mathrm{D}$ is always desirable, the same kind of test should be achieved with citation-weighted patents or other innovation measures to assess the effect of these two ownership variables on R\&D productivity (Aghion et al., 2010).

This is a challenging research program for future European projects on finance and innovation.

\section{Acknowledgments}

This work was supported by the European Commission through the FINNOV project (Finance, Innovation and Growth), Seventh Framework Program.

We would particularly like to thank Mariana Mazzucato, Giovani Dosi, William Lazonick, Paul Nightingale, Geoffrey Owen, Andrea Mina, Gulio Bottazzi and Steven Fazzari for their comments on earlier versions of this paper. 


\section{References}

Acs, Z.J., Audretsch, D.B. (1987), 'Innovation, market structure and firm size', Review of Economics and Statistics, 69(4), 567-575.

Aghion, P., Van Reenen J., Zingales L. (2010), 'Innovation and institutional ownership', WP 14769, http://www.nber.org/papers/w14769

Allen, F. (1993), 'Strategic management and financial markets, Strategic Management Journal, 14, 11-22.

Arellano, M., Bond, S. (1991), 'Some tests of specification for panel data: Monte Carlo evidence and an application to employment equations', Review of Economic Studies, 58, 277297.

Auvray, T. and Brossard, O. (2012), 'Too dispersed to monitor: ownership dispersion, monitoring and the prediction of bank distress", Journal of Money, Credit and Banking, June, 44(4).

Baysinger, B.D., Kosnik, R.D., Turk, T.A. (1991), 'Effects of Board and Ownership Structure on Corporate R\&D Strategy', Academy of Management Journal, 34(1), 205-214.

Bethel, J.E., Liebeskind, J. (1993), 'The effects of ownership structure on corporate restructuring', Strategic Management Journal, 14(Special Issue), 15-32.

Black, B.S. (1992), 'Agents watching agents: the promise of institutional investor voice', UCLA Law Review, 39, 811-893.

Black, B.S. (1998), 'Shareholder activism and corporate governance in the U.S.', The new Palgrave Dictionary of Economics and the Law, P. Newman (ed)

Blundell, R., Bond, S. (1998), 'Initial conditions and moment restrictions in dynamic paneldata models'. Journal of Econometric, 87, 115-143.

Bond, S., Meghir, C. (1994), Dynamic investment models and the firm's financial policy. Review of Economic Studies, 61, 197-222.

Bond, S., Elston, J.A., Mairesse, J., Mulkay, B. (2003), 'Financial factors and investment in Belgium, France, Germany, and the United Kingdom: A comparison using company panel data', Review of Economics and Statistics, 85, 153-165.

Bond, S., Harhoff, D., Van Reenen, J. (2005), 'Investment, R\&D and financial constraints in Britain and Germany', Annals of Economics and Statistics, 79-80, 433-460.

Bond, S., Van Reenen, J. (2007), 'Micro-economic models of investment and employment', Handbook of Econometrics, vol VI, J. Heckman, E. Leamer (eds)

Brickley, J.A., Lease, R.C., Smith, C.W. (1998), 'Ownership structure and voting on antitakeover amendments', Journal of Financial Economics, 20, 267-291.

Brown, J.R., Fazzari, S.M., Petersen, B.C. (2009), 'Financing innovation and growth: cash flow, external equity and the 1990's R\&D boom', The Journal of Finance, 64(1), 151-185.

Bushee, B. J. (1998), 'The influence of institutional investors on myopic R\&D investment Behaviour', The Accounting Review, 73(3), 305-333.

Carpenter, M., Lazonick, W., O'Sullivan, M. (2003), 'The stock market and innovative capabilities in the new economy: the optical network industry', Industrial and Corporate Change, 12(5), 963-1034. 
Chen, X., Harford, J., Li, K. (2007), 'Monitoring: Which institutions matter?', Journal of Financial Economics, 86, 279-305.

David, P., Hitt, M.A., Gimeno, J. (1996), 'The role of activism by institutional investors in influencing corporate innovation', Academy of Management Proceedings, 96, 378-382.

David, P., Hitt, M.A., Gimeno, J. (2001), 'The influence of activism by institutional investors on R\&D’, Academy Management Journal, 44 (1), 144-157.

Davis, G.F., Thompson, T.A. (1994), 'A social movement perspective on corporate control', Administrative Science Quarterly, 39, 141-173

Del Guercio, D.G., Hawkins, J. (1999), 'The motivation and impact of pension fund activism', Journal of Financial Economics, 52, 293-340

Demirag, I. (1995), 'Short-term performance pressures: is there a consensus view?', The European Journal of Finance, 1, 41-56.

Demsetz, H., Lehn, K. (1985), 'The structure of corporate ownership: Causes and consequences', The Journal of Political Economy, 93(6), 1155-1177.

Dixon, A. J., Seddighi, H.R. (1996), 'An Analysis of R\&D Activities in North East England Manufacturing Firms: The Results of a Sample Survey', Regional Studies, 30(3), 287-294.

Drucker, P.F. (1986), 'To end the raiding roulette game', Across the Board, 23(4), 30-39.

Dupuy, C., Lavigne, S., Nicet-Chenaf, D. (2010), 'Does Geography Still Matter? Evidence on the Portfolio Turnover of Large Equity Investors and Varieties of Capitalism?', Economic Geography, January, 86(1),75-98.

Eng, L.L., Shackell, M. (2001), 'The Implications of Long Term Performance Plans and Institutional Ownership for Firm's Research and Development Investments', Journal of Accounting, Auditing and Finance, 16(2), 117-39.

Faccio, M., Lang L. (2002), 'The ultimate ownership of Western European corporations', Journal of Financial Economics, 65, 365-395.

Fazzari, S. M., Hubbard, R.G., Petersen, B.C. (1988), 'Financing Constraints and corporate Investment', Brookings Papers on Economic Activity, 1, 141-195.

Ferreira, M.A., Matos, P. (2008), 'The role of institutional investors around the world', Journal of Financial Economics, 88, 499-533.

Francis, J., Smith, A. (1995), 'Agency Costs and Innovation: Some Empirical Evidence', Journal of Accounting and Economics, 19, 383-409.

Franko, L.G. (1989), 'Global corporate competition: who's winning, who's loosing and the R\&D factor as a reason why', Strategic Management Journal, 10, 449-474.

Froud, J., Haslam, C., Johal, S., Williams, K. (2000), 'Shareholder Value and Financialization: Consultancy promises, management moves', Economy and Society, 29(1), 80-110.

Gillian, S., Starks, L. (2000), 'Corporate governance proposals and shareholder activism: The role of institutional investors', Journal of Financial Economics, 57, 275-305.

Gillian, S., Starks, L. (2003), 'Corporate governance, corporate ownership, and the role of institutional investors: a global perspective', Journal of Applied Finance, 13, 4-22.

Goyer, M. (2006), 'Corporate Governance and the Innovation System in France 1985-2000', Industry and Innovation, 8(2), 135-158. 
Graves, S.B. (1988),'Institutional Ownership and Corporate R\&D in the Computer Industry', Academy of Management Journal, 31, 417-428.

Graves, S.B., Waddock, S.A. (1990), 'Institutional Ownership and Control: Implications for Long-Term Corporate Strategy’, Academy of Management Executive, Spring IV, 1, 75-83.

Hall, B. H., Mairesse, J., Branstetter, L.,Crepon, B. (1999), 'Does Cash Flow Cause Investment and R\&D: An Exploration Using Panel Data for French, Japanese and United States Scientific Firms', in Audretsch, D.B. and Thurik, R. (Eds.), Innovation, Industry Evolution, and Employment, Cambridge, UK: Cambridge University Press.

Hall, B.H. (2002), 'The financing of research and development', Oxford Review of Economic Policy, 18, 35-51.

Hansen, G.S., Hill, C.W. (1991), 'Are Institutional Investors Myopic? A Time-Series Study of Four Technology-Driven Industries’, Strategic Management Journal, 12(1), 1-16.

Hart, O. (1995), 'Corporate Governance: Some theories and implications", The Economic Journal, 195(430), 678-689.

Hausman, J.A., Taylor, W.E. (1981), 'Panel data and unobservable individual effects', Econometrica, 49, 1377-1398.

Hawley, J.P., Williams, A.T. (2000), The rise of fiduciary capitalism. How institutional investors can make America more democratic, University of Pennsylvania.

Hill, C.W., Snell, S.A. (1988), 'External Control, Corporate Strategy, and Firm Performance in Research-Intensive Industries', Strategic Management Journal, 9(6), 577-590.

Hill, C.W., Snell, S.A. (1989), 'The effects of ownership structure and control on corporate productivity', Academy of Management Journal, 32, 25-46.

Himmelberg, C.P., Petersen, B.C. (1994), 'R\&D And Internal Finance: A Panel Study of Small Firms in High-Tech Industries', Review of Economics \& Statistics,76(1), 38.

Holmström, B., Tirole, J. (1993), 'Market liquidity and performance monitoring', The Journal of Political Economy, 101, 678-709.

Hoskisson, R.E., Hitt, M.A., Johnson, R.A., Grossman, W. (2002), 'Conflicting Voices: The Effects of Institutional Ownership Heterogeneity and Internal Governance on Corporate Innovation Strategies', Academy of Management Journal, 45(4), 697-716.

Hubbard, R. G. (1998), 'Capital-market Imperfections and Investment', Journal of Economic

Literature, 36, 193-225.

Jacobs, M. (1991), Short-Term America. The causes and cures of our business myopia, Boston, M.A, Harvard Business School Press.

Jarell, G.A., Lehn, K., Marr W. (1985), 'Institutional ownership, tender offers and long term investment', Office of the Chief Economist, Securities and Exchange Commission, Washington D.C.

Jensen, M. (1986), 'Agency costs of free cash flows. Corporate finance and takeovers', American Economic Review, 76(2), 323-329.

Kaplan, S.N., Minton, B. (2012), 'How has CEO turnover changed?', International Review of Finance, 12(1), 57-87.

Kochhar, R., David, P. (1996), 'Institutional investors and firm innovation: a test of competing hypotheses', Strategic Management Journal, 17, 73-84. 
Khorana, A. (1996), 'Top management turnover: An investigation of mutual fund managers', Journal of Financial Economics, 40, 403-427.

La Porta, R., Lopez-de-Silanes, F., Shleifer, A. (1999), 'Corporate ownership around the world', Journal of Finance, 54, 471-517.

Lazonick, W. (2009), Sustainable prosperity in the New Economy? Business organization and high-tech employment in the United States, W.E. Upjohn Institute for Employment Research.

Lazonick, W. (2007), 'The US Stock Market and the Governance of Innovative Enterprise', Industrial and Corporate Change, 16(6), 983-1035.

Lazonick, W., O' Sullivan, M. (2000), 'Maximizing shareholder value: a new ideology for corporate governance', Journal Economy and Society, 29 (1), 13-35.

Markowitz, H.M. (1952), 'Portfolio selection', Journal of Finance, 77-91.

Maug, E. (1998), 'Large shareholders as monitors: Is there a trade-off between liquidity and control?' The Journal of Finance, 53(1), 595-612.

Mazzucato, M. (2000), Firm size, innovation and market structure, Edward Elgar Publishing.

McConnell, J., Servaes, H. (1990), 'Additional evidence on equity ownership and corporate value', Journal of Financial Economics, 27, 595-612.

Mina A., Lahr H., Hugues A. (2012), 'The demand and supply of external finance for innovative firms', International Schumpeter Society Conference, University of Queensland.

Mitroff, I.I. (1987), Business not as usual. Jossey-Bass, San Francisaco, C.A.

Monks, R., Minow N. (1995), Corporate Governance, Blackwell Publishing, Cambridge, MA.

Mulkay, B., Hall, B.H., Mairesse, J. (2001), 'Investment and R\&D in France and in the United States', in Deutsche Bundesbank, ed.: Investing Today for the World of Tomorrow (Spring Verlag, Dresden).

O'Sullivan, M. (2004), The Oxford handbook of innovation, Oxford University Press.

O'Sullivan, M. (2000), 'The Innovative Enterprise and Corporate Governance', Cambridge Journal of Economics, 24, 393-416.

Ortega-Argilés, R., Moreno, R., Caralt, J. (2005), 'Ownership structure and innovation: is there a real link?', The Annals of Regional Science, Springer, 39(4), 637-662.

Pound, J. (1988), 'Proxy contests and the efficiency of shareholder oversight', Journal of Financial Economics, 20, 237-265.

Porter, M.E. (1992), 'Capital disadvantage: America's failing capital system investment', Harvard Business Review, 70, 65-82.

Roe, M.J. (1991), 'Political and legal restraints on ownership and control of public companies', Journal of Financial Economics, 27, 7-41.

Schumpeter, J.A. (1942), Capitalism, Socialism and Democracy, New York, Harper and Row.

Sherman, H., Beldona, S., Joshi M.P. (1998), 'Institutional Investor Heterogeneity: Implications for Strategic Decisions', Corporate Governance, 6 (3), 166-173.

Shleifer, A., Vishny, R.W. (1986), 'Large shareholders and corporate control', Journal of Political Economy, 94 (3), 461-488. 
Shleifer, A., Vishny, R.W. (1997), 'A survey of corporate governance', Journal of Finance 52, 737-782.

Useem M. (1993), Executive defense: shareholder power and corporate reorganization, Harvard University Press, Cambridge, MA.

Van Cayseele, P.J.G. (1998), 'Market Structure and Innovation: A Survey of the Last Twenty Years', The Economist, 146 (3), 391-417.

Wahal, S., McConnell, J. (2000), 'Do institutional investors exacerbate managerial myopia?', Journal of Corporate Finance, 6, 307-329.

Williams, K. (2000), 'From shareholder value to present-day capitalism', Economy and Society, 29(1), 1-12.

Zahra, S.A. (1996), 'Governance, ownership and corporate entrepreneurship: the moderating impact of industry technological opportunities', Academy of Management Journal, 39, 17131735 
Table 1: Summary statistics of variables tested

All variables are constructed yearly at the firm level for the sample of 324 firms that have been constantly classified in the top 1000 EU companies for R\&D investment during $2002-2009$.

\begin{tabular}{|c|c|c|c|c|c|c|}
\hline Variables & Définitions & Obs. & Mean & Std. Dev. & Min & Max \\
\hline \multicolumn{7}{|c|}{ INDEPENDENT variables } \\
\hline rdtoassets & R\&D expenses / assets & 2525 & 0,06 & 0,08 & 0,0002 & 0,9839 \\
\hline rdtosales & $R \& D$ expenses / sales & 2525 & 0,09 & 0,25 & 0,0003 & 7,0291 \\
\hline \multicolumn{7}{|c|}{ DEPENDENT variables } \\
\hline tobing & Tobin's $Q=$ (market capitalisation+total debt) / total asset & 2519 & 1,38 & 1,13 & 0,25 & 9,88 \\
\hline salestoassets & sales / total asset & 2525 & 0,97 & 0,42 & 0,01 & 3,12 \\
\hline ros & Return on sales $=$ net income $/$ sales & 2525 & 0,01 & 0,33 & $-6,99$ & 1,19 \\
\hline hightech & dummy $=1$ if "high tech" industry according to the OECD classification & 2525 & 0,44 & 0,50 & 0 & 1 \\
\hline midhightech & dummy $=1$ if "mid-high tech" industry according to the OECD classification & 2525 & 0,27 & 0,44 & 0 & 1 \\
\hline midlowtech & dummy $=1$ if "mid-low tech" industry according to the OECD classification & 2525 & 0,19 & 0,40 & 0 & 1 \\
\hline lowtech & dummy $=1$ if "low tech" industry according to the OECD classification & 2525 & 0,10 & 0,30 & 0 & 1 \\
\hline UK & dummy $=1$ if the firm's headquarter is in the United Kingdom & 2525 & 0,26 & 0,44 & 0 & 1 \\
\hline German & dummy $=1$ if the firm's headquarter is in Germany, Austria, Luxembourg or Poland & 2525 & 0,25 & 0,44 & 0 & 1 \\
\hline Nordic & dummy $=1$ if headquarter in Denmark, Finland, Sweden, Netherlands & 2525 & 0,26 & 0,44 & 0 & 1 \\
\hline Latin & dummy $=1$ if the firm's headquarter is in France, Italy, Spain, Greece or Belgium & 2525 & 0,23 & 0,42 & 0 & 1 \\
\hline employees & Total number of employees in the company & 2525 & 27959,69 & 57646,76 & 56 & 524803 \\
\hline debttoinc & total debt / net income & 2525 & 3,90 & 65,31 & $-1566,82$ & 1412,78 \\
\hline cashtoinc & Cash in the balance sheet / net income & 2525 & 1,42 & 19,53 & $-678,88$ & 534,40 \\
\hline buybacktoinc & Stock repurchases / net income & 2522 & 0,10 & 1,63 & $-67,34$ & 27,52 \\
\hline divtoincome & Total dividends / net income & 2522 & 0,26 & 4,22 & $-156,00$ & 50,78 \\
\hline duii & dummy $=1$ if ownership is dominated by institutional investors & 2525 & 0,60 & 0,49 & 0 & 1 \\
\hline duindep & dummy $=1$ if ownership is dominated by independent investors & 2525 & 0,58 & 0,49 & 0 & 1 \\
\hline c1 1 & $\%$ of total outstanding shares owned by the main shareholder & 2525 & 20,43 & 17,82 & 0,13 & 90,79 \\
\hline c5 & $\%$ of total outstanding shares owned by the five main shareholders & 2528 & 37,47 & 19,92 & 0,4 & 98,57 \\
\hline iistake & holdings of institutional investors in the ten most important shareholders (\%) & 2528 & 23,72 & 16,14 & 0 & 98,59 \\
\hline stratstake & holdings of strategic entities in the ten most important shareholders (\%) & 2525 & 20,85 & 23,05 & 0 & 94,59 \\
\hline impatientstake & holdings of impatient investors in the ten most important shareholders(\%) & 2525 & 5,22 & 6,70 & 0 & 74,71 \\
\hline duanglo & dummy $=1$ if ownership is dominated by anglo-saxon investors & 2525 & 0,35 & 0,48 & 0 & 1 \\
\hline dueurope & dummy = 1 if ownership is dominated by european investors & 2525 & 0,64 & 0,48 & 0 & 1 \\
\hline
\end{tabular}


Table 2: Distribution of investors categories among the $1^{\text {st }}, 5^{\text {th }}$ and $10^{\text {th }}$ main shareholders

\begin{tabular}{lcc|cc|cc|c|c|c}
\hline & & & & & strategic & $\begin{array}{c}\text { strategic } \\
\text { patient }\end{array}$ & $\begin{array}{c}\text { institutional } \\
\text { \& impatient }\end{array}$ & $\begin{array}{c}\text { institutional } \\
\text { \& patient }\end{array}$ \\
\hline 1st shareholder & $49,07 \%$ & $50,93 \%$ & $11,04 \%$ & $88,96 \%$ & $0,00 \%$ & $100,00 \%$ & $20,82 \%$ & $79,18 \%$ \\
5th shareholder & $89,86 \%$ & $10,14 \%$ & $23,71 \%$ & $76,29 \%$ & $0,00 \%$ & $100,00 \%$ & $24,46 \%$ & $75,54 \%$ \\
10th shareholder & $93,35 \%$ & $6,65 \%$ & $25,51 \%$ & $74,49 \%$ & $0,00 \%$ & $100,00 \%$ & $25,33 \%$ & $74,67 \%$ \\
\hline
\end{tabular}

Table 2': Nature of the 'patient' and 'impatient' institutional investors of the sample

\begin{tabular}{|c|c|c|c|c|c|c|c|}
\hline \multicolumn{4}{|c|}{ Who are the impatient ${ }^{1}$ institutional investors? } & \multicolumn{4}{|c|}{ Who are the patient ${ }^{1}$ institutional investors? } \\
\hline $\begin{array}{l}\% \text { of impatient institutional } \\
\text { investors whose type is: }\end{array}$ & $\begin{array}{c}1^{\text {st }} \\
\text { shareholder }\end{array}$ & $\begin{array}{l}5^{\text {th }} \\
\text { shareholder }\end{array}$ & $\begin{array}{c}10^{\text {th }} \\
\text { shareholder }\end{array}$ & $\begin{array}{l}\% \text { of patient institutional } \\
\text { investors whose type is: }\end{array}$ & $1^{\text {st }}$ shareholder & $\begin{array}{l}5^{\text {th }} \\
\text { shareholder }\end{array}$ & $\begin{array}{c}10^{\text {th }} \\
\text { shareholder }\end{array}$ \\
\hline Investment advisors & $53,15 \%$ & $72,56 \%$ & $68,24 \%$ & Investment advisors & $49,46 \%$ & $54,59 \%$ & $55,79 \%$ \\
\hline Hedge funds & $39,37 \%$ & $24,19 \%$ & $26,55 \%$ & Hedge funds & $33,05 \%$ & $32,47 \%$ & $30,57 \%$ \\
\hline Private equity & $1,97 \%$ & $0,18 \%$ & $1,01 \%$ & Private equity & $3,43 \%$ & $0,44 \%$ & $0,19 \%$ \\
\hline Venture capital funds & $3,15 \%$ & $0,36 \%$ & $0,34 \%$ & Venture capital funds & $3,22 \%$ & $0,88 \%$ & $0,50 \%$ \\
\hline Pension funds & $0,00 \%$ & $0,00 \%$ & $0,00 \%$ & Pension funds & $4,61 \%$ & $5,15 \%$ & $5,85 \%$ \\
\hline Banks \& trusts & $0,39 \%$ & $1,81 \%$ & $1,85 \%$ & Banks \& trusts & $2,90 \%$ & $4,08 \%$ & $4,98 \%$ \\
\hline Research firms & $0,79 \%$ & $0,72 \%$ & $1,01 \%$ & Research firms & $0,00 \%$ & $0,00 \%$ & $0,00 \%$ \\
\hline Total & $98,82 \%$ & $99,82 \%$ & $98,99 \%$ & Total & $96,67 \%$ & $97,61 \%$ & $97,88 \%$ \\
\hline
\end{tabular}

Table 2": Time horizon of the main institutional investors of the sample

\begin{tabular}{lcccccc}
\hline & \multicolumn{2}{c}{$1^{\text {st }}$ shareholder } & \multicolumn{2}{c}{$5^{\text {th }}$ shareholder } & \multicolumn{2}{c}{$10^{\text {th }}$ shareholder } \\
& Impatient & Patient & Impatient & Patient & Impatient & Patient \\
\hline Investment advisors & $22,65 \%$ & $77,35 \%$ & $31,63 \%$ & $68,37 \%$ & $31,18 \%$ & $68,82 \%$ \\
Hedge funds & $24,51 \%$ & $75,49 \%$ & $20,58 \%$ & $79,42 \%$ & $24,35 \%$ & $75,65 \%$ \\
Private equity & $13,51 \%$ & $86,49 \%$ & $12,50 \%$ & $87,50 \%$ & $66,67 \%$ & $33,33 \%$ \\
Venture capital funds & $21,05 \%$ & $78,95 \%$ & $12,50 \%$ & $87,50 \%$ & $20,00 \%$ & $80,00 \%$ \\
Pension funds & $0,00 \%$ & $100,00 \%$ & $0,00 \%$ & $100,00 \%$ & $0,00 \%$ & $100,00 \%$ \\
Banks \& trusts & $3,57 \%$ & $96,43 \%$ & $13,33 \%$ & $86,67 \%$ & $12,09 \%$ & $87,91 \%$ \\
Research firms & $100,00 \%$ & $0,00 \%$ & $100,00 \%$ & $0,00 \%$ & $100,00 \%$ & $0,00 \%$ \\
\hline
\end{tabular}

1 'impatient' investors have a portfolio holding period of less than 24 months. 'Patient investors have a holding period of more than 24 months. 
Table 3: the good and bad side of institutional investors (Blundell-Bond system dynamic estimation, panel of 324 European companies over 2002-2009)

\begin{tabular}{|c|c|c|c|}
\hline & $\begin{array}{c}\text { (1) } \\
\text { rdtoassets }\end{array}$ & $\begin{array}{c}(2) \\
\text { rdtoassets } \\
\text { (demand \& financial } \\
\text { variables included) }\end{array}$ & $\begin{array}{c}(3) \\
\text { rdtoassets } \\
\text { (scale variables } \\
\text { winsorized) }\end{array}$ \\
\hline rdtoassets $_{\mathrm{t}-1}$ & $\begin{array}{c}0.504 * * * \\
(0.0690)\end{array}$ & $\begin{array}{c}0.477 * * * \\
(0.0652)\end{array}$ & $\begin{array}{c}0.478 * * * \\
(0.0702)\end{array}$ \\
\hline Tobinq & $\begin{array}{c}0.00299 \\
(0.00416)\end{array}$ & $\begin{array}{c}0.00327 \\
(0.00396)\end{array}$ & $\begin{array}{c}0.00236 \\
(0.00407)\end{array}$ \\
\hline salestoassets & & $\begin{array}{c}0.0301 * * * \\
(0.00905)\end{array}$ & $\begin{array}{c}0.0381 * * * \\
(0.0104)\end{array}$ \\
\hline lemployees & $\begin{array}{l}-0.00699 \\
(0.00655)\end{array}$ & $\begin{array}{l}-0.0158 * * \\
(0.00756)\end{array}$ & $\begin{array}{c}-0.0102 \\
(0.00671)\end{array}$ \\
\hline $\operatorname{ros}_{\mathrm{t}-1}$ & $\begin{array}{c}0.00978 * * * \\
(0.00252)\end{array}$ & $\begin{array}{c}0.00886 * * * \\
(0.00291)\end{array}$ & $\begin{array}{c}0.00956 * * * \\
(0.00259)\end{array}$ \\
\hline duii & $\begin{array}{l}0.0372 * \\
(0.0199)\end{array}$ & $\begin{array}{l}0.0347^{*} \\
(0.0200)\end{array}$ & $\begin{array}{l}0.0411 * \\
(0.0211)\end{array}$ \\
\hline impatientstake & $\begin{array}{c}-0.00280 * * \\
(0.00138)\end{array}$ & $\begin{array}{c}-0.00331 * * \\
(0.00131)\end{array}$ & $\begin{array}{c}-0.00316 * * \\
(0.00149)\end{array}$ \\
\hline hightech & $\begin{array}{l}0.105^{* * *} \\
(0.0409)\end{array}$ & $\begin{array}{l}0.0696 * \\
(0.0373)\end{array}$ & $\begin{array}{c}0.125 * * * \\
(0.0479)\end{array}$ \\
\hline latin & $\begin{array}{c}0.0800 \\
(0.0583)\end{array}$ & $\begin{array}{l}0.0727 * \\
(0.0429)\end{array}$ & $\begin{array}{c}0.104 * \\
(0.0621)\end{array}$ \\
\hline german & $\begin{array}{c}0.0914 \\
(0.0653)\end{array}$ & $\begin{array}{c}0.0451 \\
(0.0437)\end{array}$ & $\begin{array}{c}0.110 \\
(0.0725)\end{array}$ \\
\hline nordic & $\begin{array}{l}-0.00603 \\
(0.0497)\end{array}$ & $\begin{array}{l}-0.00931 \\
(0.0413)\end{array}$ & $\begin{array}{l}-0.00530 \\
(0.0530)\end{array}$ \\
\hline debttoinc & & $\begin{array}{l}-0.0000302 \\
(0.0000383)\end{array}$ & \\
\hline cashtoinc & & $\begin{array}{c}0.0000386 \\
(0.0000337)\end{array}$ & \\
\hline divtoincome & & $\begin{array}{c}0.000158 \\
(0.000485)\end{array}$ & \\
\hline buybacktoinc & & $\begin{array}{c}0.00273 \\
(0.00410)\end{array}$ & \\
\hline Observations & 1874 & 1873 & 1874 \\
\hline
\end{tabular}

\section{Arellano-Bond tests for zero autocorrelation in first-differenced} errors

$\begin{array}{llrlr}\text { H0: no order } & 1 & p=0.048 & p=0.051 & P=0.054 \\ \text { autocorrelation } & & \\ \text { H0: no order } & 2 & p=0.570 & p=0.384 & p=0.594 \\ \text { autocorrelation } \\ \begin{array}{l}\text { Sargan test of overidentifying restrictions } \\ \text { H0: overidentifying } \quad p=0.336\end{array} & p=0.131 & p=0.626\end{array}$

restrictions are valid

Robust standard errors in parentheses. ${ }^{*} p<0.1,{ }^{* *} p<0.05,{ }^{* * *} p<0.01$. All models estimated with time-period fixed effects and a constant. Coefficients, robust standard errors and $p$ values of the Arellano-Bond autocorrelation test are obtained after a one step system-GMM estimation. The Sargan statistic is computed with the two step systemGMM estimation results. The instrumented variables are duinvins, partshortterm and ros $_{t-1}$ (treated as predetermined). 
Table 4: interacting ownership effects with firm size (system dynamic estimation, panel of 324 companies over 2002-2009)

$\begin{array}{ll}\text { (1) Interacting ownership with size } & \text { (2) Testing the non linearity of the impatient capital effect }\end{array}$

\begin{tabular}{|c|c|c|c|}
\hline & rdtoassets & & rdtoassets \\
\hline rdtoassets $_{\mathrm{t}-1}$ & $\begin{array}{c}0.476 * * * \\
(0.0654)\end{array}$ & rdtoassets $_{\mathrm{t}-1}$ & $\begin{array}{c}0.493 * * * \\
(0.0646)\end{array}$ \\
\hline tobinq1 & $\begin{array}{c}0.00239 \\
(0.00390)\end{array}$ & tobinq1 & $\begin{array}{c}0.00247 \\
(0.00406)\end{array}$ \\
\hline salestoassets & $\begin{array}{c}0.0341 * * * \\
(0.00921)\end{array}$ & salestoassets & $\begin{array}{c}0.0337 * * * \\
(0.00964)\end{array}$ \\
\hline lemployees & $\begin{array}{l}-0.00961 \\
(0.00760)\end{array}$ & lemployees & $\begin{array}{l}-0.0147 * * \\
(0.00614)\end{array}$ \\
\hline $\operatorname{ros}_{\mathrm{t}-1}$ & $\begin{array}{c}0.00760 * * \\
(0.00337)\end{array}$ & $\operatorname{ros}_{\mathrm{t}-1}$ & $\begin{array}{c}0.00926 * * * \\
(0.00277)\end{array}$ \\
\hline dbig $\times$ duii & $\begin{array}{c}0.0358 * * \\
(0.0173)\end{array}$ & duii & $\begin{array}{c}0.0368 * * \\
(0.0182)\end{array}$ \\
\hline$(1-$ dbig $) \times$ duii & $\begin{array}{c}0.0450 * * \\
(0.0199)\end{array}$ & & \\
\hline dbig $\times$ impatientstake & $\begin{array}{l}0.000173 \\
(0.00154)\end{array}$ & $(1-$ dhighturnov $) \times$ impatientstake & $\begin{array}{c}-0.0034 \\
(0.00835)\end{array}$ \\
\hline$(1-$ dbig $) \times$ impatientstake & $\begin{array}{c}-0.00335 * * * \\
(0.00123)\end{array}$ & dhighturnov $\times$ impatientstake & $\begin{array}{c}-0.00282 * * \\
(0.00133)\end{array}$ \\
\hline hightech & $\begin{array}{c}0.0905 * * * \\
(0.0249)\end{array}$ & hightech & $\begin{array}{c}0.0802 * * * \\
(0.0307)\end{array}$ \\
\hline latin3 & $\begin{array}{c}0.0392 \\
(0.0336)\end{array}$ & latin3 & $\begin{array}{l}0.0788^{*} \\
(0.0461)\end{array}$ \\
\hline german2 & $\begin{array}{c}0.0356 \\
(0.0260)\end{array}$ & german2 & $\begin{array}{l}0.0770 * \\
(0.0462)\end{array}$ \\
\hline nordic & $\begin{array}{l}-0.0135 \\
(0.0326)\end{array}$ & nordic & $\begin{array}{c}-0.00206 \\
(0.0411)\end{array}$ \\
\hline Observations & 1874 & Observations & 1874 \\
\hline
\end{tabular}

Arellano-Bond tests for zero autocorrelation in first-differenced errors

$\begin{array}{llcl}\mathrm{H} 0: \quad \text { no order } & 1 & p=0.033 & p=0.050 \\ \text { autocorrelation } & & p=0.648 & p=0.570 \\ \mathrm{H} 0 \text { : no order } & 2 & p & \\ \text { autocorrelation } & & \end{array}$

\section{Sargan test of overidentifying restrictions}
H0:
overidentifying
$p=0.753$
$p=0.433$

restrictions are valid

Robust standard errors in parentheses. ${ }^{*} p<0.1,{ }^{* *} p<0.05,{ }^{* * *} p<0.01$. All models estimated with time-period fixed effects and a constant. Coefficients, robust standard errors and p values of the Arellano-Bond autocorrelation test are obtained after a one step system-GMM estimation. The Sargan statistic is computed with the two step systemGMM estimation results. The instrumented variables are (1-dbig)xduii, dbigxduii, dbigximpatientstake, (1-dbig)ximpatientstake, $\operatorname{ros}_{t-1}$ (treated as predetermined) in the first equation, and duii, dhighturnov $x$ impatientstake, (1-dhighturnov)ximpatientstake and ros $_{t-1}$ (treated as predetermined) in the second equation. 


\begin{tabular}{|c|c|c|c|c|c|c|c|}
\hline 2-digits SIC & Sectors & Frequence & Percentage & 4-digits SIC & Most frequent sectors & Frequence & Percentage \\
\hline 1 & Agricultural production & 8 & 0.32 & 7372 & Prepackaged software & 197 & 7.80 \\
\hline 10 & Metal mining & 38 & 1.50 & 2834 & Pharmaceutical preparations & 153 & 6.06 \\
\hline 13 & Oil and gas & 29 & 1.15 & 3674 & Semiconductors \& related devices & 101 & 4.00 \\
\hline 14 & Nonmetallic Minerals & 8 & 0.32 & 3663 & Radio \& TV broadcasting equipment & 69 & 2.73 \\
\hline 15 & General Building Contractors & 12 & 0.48 & 3714 & Motor vehicule parts \& accessories & 64 & 2.53 \\
\hline 16 & Heavy Construction, Except Building & 8 & 0.32 & 4813 & Telephone communications except radio & 64 & 2.53 \\
\hline 20 & Food and kindred products & 104 & 4.12 & 3711 & Motor vehicules \& passenger car bodies & 47 & 1.86 \\
\hline 21 & Tobacco Products & 16 & 0.63 & 3845 & Electromedical/Therapeutic apparatus & 46 & 1.82 \\
\hline 23 & Apparel \& Other Textile Products & 8 & 0.32 & 3679 & Electronic components $\mathrm{Nec}$ & 42 & 1.66 \\
\hline 24 & Lumber \& Wood Products & 7 & 0.28 & 3559 & Special industry machinery Nec & 37 & 1.47 \\
\hline 25 & Furniture \& Fixtures & 8 & 0.32 & & & & \\
\hline 26 & Paper \& Allied Products & 24 & 0.95 & & & & \\
\hline 27 & Printing \& Publishing & 16 & 0.63 & & & & \\
\hline 28 & Chemicals and allied products & 336 & 13.31 & & & & \\
\hline 29 & Petroleum \& Coal Products & 24 & 0.95 & & & & \\
\hline 30 & Rubber and Misc. Plastic products & 64 & 2.53 & & & & \\
\hline 32 & Stone, clay and glass products & 56 & 2.22 & & & & \\
\hline 33 & Primary metal industries & 80 & 3.17 & & & & \\
\hline 34 & fabricated metal products & 64 & 2.53 & & & & \\
\hline 35 & Industrial machinery and equipment & 301 & 11.92 & & & & \\
\hline 36 & Electronic and electric equipment & 346 & 13.70 & & & & \\
\hline 37 & Transportation equipment & 199 & 7.88 & & & & \\
\hline 38 & Instruments and related products & 195 & 7.72 & & & & \\
\hline 39 & Misc. Manuf. Industries & 16 & 0.63 & & & & \\
\hline 45 & Transportation by Air & 16 & 0.63 & & & & \\
\hline 47 & Transportation Services & 8 & 0.32 & & & & \\
\hline 48 & Communication & 104 & 4.12 & & & & \\
\hline 49 & Electric, gas and sanitary services & 67 & 2.65 & & & & \\
\hline 50 & Wholesale trade & 32 & 1.27 & & & & \\
\hline 51 & Wholesale Trade- Nondurable Goods & 8 & 0.32 & & & & \\
\hline 62 & Security \& Commodity Brokers & 8 & 0.32 & & & & \\
\hline 73 & Business services & 283 & 11.21 & & & & \\
\hline 76 & Miscellaneous Repair Services & 8 & 0.32 & & & & \\
\hline 87 & Engineering \& Management Services & 24 & 0.95 & & & & \\
\hline Total & & 2533 & 100.00 & & & & \\
\hline
\end{tabular}




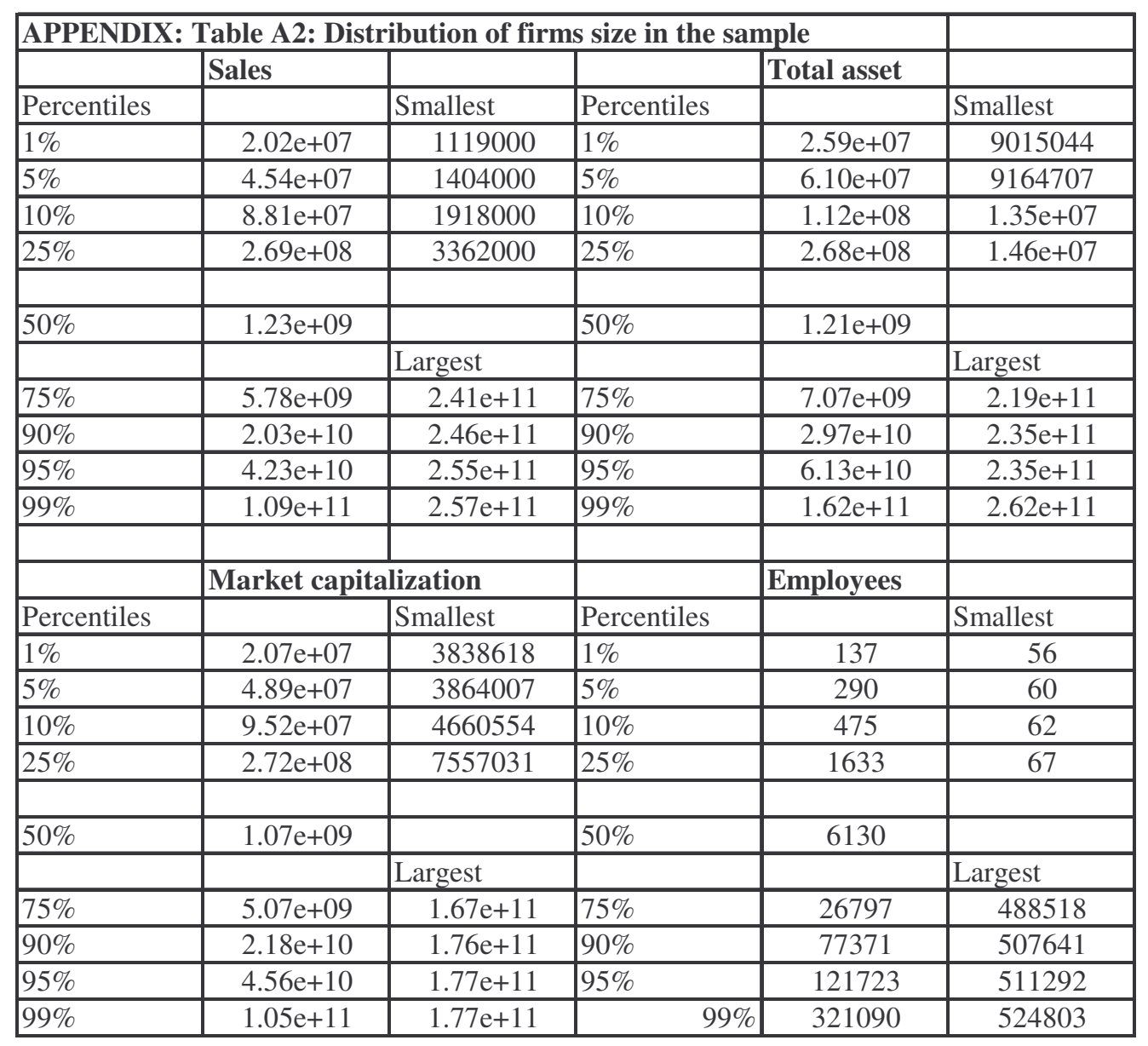

APPENDIX. Table A3. Sample's country distribution

\begin{tabular}{|lccc|}
\hline Country & Frequency & $\begin{array}{c}\text { \% of firms in the } \\
\text { sample }\end{array}$ & $\begin{array}{c}\text { Relative size of the } \\
\text { country }\end{array}$ \\
U.K. & 608 & 24.08 & 14,69 \\
Germany & 557 & 22.06 & 19,20 \\
France & 346 & 13.70 & 14,78 \\
Sweden & 206 & 8.16 & 2,13 \\
Finland & 185 & 7.33 & 1,23 \\
Netherlands & 128 & 5.07 & 3,86 \\
Denmark & 125 & 4.95 & 1,30 \\
Belgium & 98 & 3.88 & 2,58 \\
Italy & 83 & 3.29 & 14,12 \\
Austria & 72 & 2.85 & 1,93 \\
Spain & 48 & 1.90 & 10,83 \\
Ireland & 39 & 1.54 & 1,09 \\
Greece & 15 & 0.59 & 2,65 \\
Poland & 8 & 0.32 & 9,01 \\
Luxembourg & 7 & 0.28 & 0,12 \\
TOTAL & 2,525 & 100.00 & \\
\hline
\end{tabular}

${ }^{1} \%$ of the country's population in the total population of the sample's countries 
${ }^{\mathrm{i}}$ See Acs \& Audretsch (1987) and Mazzucato (2000) for a discussion of the hypothesis that innovation activity is promoted by large firms. See Fazzari, Hubbard, Petersen (1988), Himmelberg \& Petersen (1994), Hall (2002), O'Sullivan (2004) and Brown, Fazzari, Petersen (2009) for surveys on financing constraints and innovative investments.

ii See La Porta, Lopez-de-Silanes, Shleifer (1999) for a survey on conflicts of interests between controlling shareholders and minority shareholders.

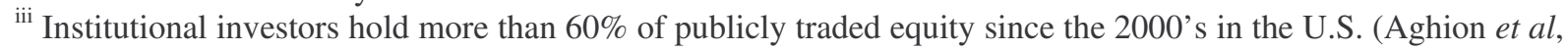
2010).

iv Activism refers to actions taken by institutional investors to pressure managers (public announcements, shareholder proposals, proxy contests, direct negotiations with managers, etc. (David et al., 2001).

${ }^{\vee}$ State or family capitalism.

${ }^{v i}$ Proposals are often targeted at companies that have underperformed their peers and can include i) redeem a company's poison pill; ii) replace directors; iii) separate the position of Chairman of the Board and Chief Executive Officer, iv) create a compensation committee, etc. See Black (1998), Del Guercio \& Hawkins (1999), Gillian \& Starks (2000).

vii In particular, we are not able to analyse the influence of pension funds or 'grey' investors on R\&D. Pension funds have too small direct shareholdings in companies and the category 'grey' investors overlap the category 'strategic' investors (we explain this point in paragraph 3.).

viii An alternative source of European R\&D data is Eurostat statistics on Business Expenditure on R\&D (BERD), but this is aggregated data that cannot be used for firm-level studies. Moreover, BERD figures include all R\&D expenses whereas the EU Scoreboard R\&D figures only include the R\&D financed by companies from their own funds.

ix The Scoreboard allocates each company's total R\&D investment to the country in which the company has its registered office.

${ }^{x}$ Any company that is not ranked in Scoreboard for a single year between 2004 and 2009 is excluded from the sample.

${ }^{x i}$ Because we merge these data with ownership data that are not available before 2002, we cannot exploit years 2000 and 2001.

xii We fill out the missing figures through annual financial reports. Ownership information from the TOBO database is the ownership at the end of the calendar year, but for other financial variables we consider the fiscal year-end month because it is also the methodology used to produce R\&D figures in the EU Scoreboard. Consequently, fiscal years ending between January 1st and May 31st are considered as ending in the prior calendar year. For example, the data for a fiscal year beginning on June 1st, 2008 and ending on May 31st, 2009 is reported as the year 2008, whereas a fiscal year beginning on July 1st, 2008 and ending on June 30th, 2009 is reported as the year 2009 .

${ }^{\text {xiii }}$ See Hall (2002) for a survey on the financing of R\&D investment.

${ }^{\text {xiv }}$ We also tested equations with $\mathrm{R} \& \mathrm{D} / \mathrm{sales}$ as the dependent variable, and the results proved much less robust than in the case of R\&D/assets. A plausible explanation is that sales are more volatile than the book value of assets, which is supported by the much higher standard error of the R\&D-to-sales ratio than the R\&D-to-assets ratio (Table 1). The influence of ownership characteristics may consequently be hidden by sales volatility when 
one measures the $R \& D$ effort by $R \& D$-to-sales ratios. The $R \& D$-over-assets ratio is a more structural measure of a firm's R\&D effort, reflecting the long term R\&D policy of the firm. It is therefore more responsive to structural ownership characteristics. It also appears to be more reactive to long-term determinants such as the technological level or the country group effect. The number of employees is a measure of firms' size only in labour-intensive industrial sectors.

${ }^{\mathrm{xv}}$ For these country group dummies, the reference is therefore $u k$ which is the dummy for English or Irish companies.

${ }^{\text {xvi }}$ We use log (employees) in the regressions while it appears in level in Table 1.

${ }^{x v i i}$ The Blundell-Bond estimator is also preferred to the Arellano-Bond version because it has greater precision when the time dimension of the sample is small and the true value of the parameter $\beta_{l}$ is large.

${ }^{\text {xviii }}$ Results of such static specification can be provided on demand.

xix Showing this directly in the estimates with crossed dummies proved impossible because the category 'strategic' and the category 'impatient' investors is too small: too few ownership structures are dominated by 'impatient' investors. 